\title{
Molecular analysis of S. paratyphi A from an outbreak in New Delhi, India
}

\author{
K.L. Thong, S. Nair, R. Chaudhry*, P. Seth*, A. Kapil*, T. Pang
}

\begin{abstract}
Abstrak
Kejadian luar biasa (KLB) demam enterik yang disebabkan oleh S. paratyphi $A$ belum pernah dilaporkan sampai terjadinya KLB tersebut di New Delhi, India selama bulan September dan Oktober 1996. Telah dilakukan analisis molekuler dari 13 isolat KLB dan 5 isolat sporadik S. paratyphi A menggunakan pulsed-field gel electrophoresis (PFGE) dan ribotyping. DNA genom didigesti dengan ensim restriksi Xbal dan SpeI sebelum analisis PFGE dan ribotyping menggunakan pelacak gen $r R N A$ yang berasal dari plasmid pKK3535. Pada PFGE, 5 isolat sporadik mempunyai 5 pola pita DNA yang unik/ berbeda ( $F$, koefisien kemiripan, 0,63-0,76), dari 13 isolat $K L B$ ditemukan 4 pola $P F G E$ yang erat hubungannyalmirip $(F$ 0,8-1,0). Tidak satupun pola isolat sporadik ditemukan pada strain KLB. Pola yang ditemukan ini berbeda dari strain S. paratyphi A Malaysia. Hasil yang serupa diperoleh dari ribotyping, walaupun lebih sedikit pita DNA yang diamati dibandingkan pada PFGE. Hasil-hasil yang diperoleh ini mengkonfirmasi penemuan sebelumnya mengenai S. typhi yang mana isolat KLB ternyata lebih klonal dan homogen dibandingkan isolat sporadik. Data ini juga memastikan kegunaan metode typing molekuler dalam membedakan Salmonellae untuk tujuan epidemiologi.
\end{abstract}

\begin{abstract}
Outbreaks of enteric fever caused by S. paratyphi A has never been reported until an outbreak occurred in New Delhi, India during September and October, 1996. We performed molecular analysis of 13 outbreak and 5 sporadic isolates of S. paratyphi $A$ from this outbreak using pulsed-field gel electrophoresis (PFGE) and ribotyping. Genomic DNA were digested with Xbal and SpeI prior to PFGE analysis and ribotyping was performed using an rRNA gene probe derived from plasmid pKK3535. By PFGE using both restriction endonucleases, the 5 sporadic isolates had 5 different/unique DNA band patterns ( $F$, coefficien of similarity, 0.63-0.76) whereas 4 closelyrelated PFGE patterns (F 0.8-1.0) were noted among the 13 outbreak isolates. None of the patterns present among the sporadic isolates were seen among the outbreak strains. The patterns observed were also different compared to Malaysian S. paratyphi $A$ strains. Similar results were seen with ribotyping although fewer DNA bands were seen as compared to PFGE. These results confirm the findings previously observed with $\mathrm{S}$. typhi in that outbreak isolates are more clonal and homogeneous compared to sporadic isolates. The data also reaffirms the usefullness of molecular typing methods in the discrimination of salmonellae for epidemiological purposes.
\end{abstract}

Institute of Postgraduate Studies \& Research,

University of Malaya. Kuala Lumpur, Malaysia;

*Department of Medical Microbiology,

All India Institute of Medical Sciences, New Delhi, India. 